De Jure: Jurnal Hukum dan Syari'ah

Vol. 9, No. 2, 2017, h. 88-104

ISSN (Print): 2085-1618, ISSN (Online): 2528-1658

DOI: http://dx.doi.org/10.18860/j-fsh.v9i2.6905

Available online at http://ejournal.uin-malang.ac.id/index.php/syariah

\title{
Kekerasan Dalam Rumah Tangga dan Sanksinya dalam Hukum Islam
}

\author{
Ali Kadarisman \\ UIN Maulana Malik Ibrahim Malang, Indonesia \\ alikadarisman@gmail.com
}

\begin{abstract}
Abstrak:
Penelitian ini ditujukan untuk memberikan gambaran tentang bentuk-bentuk kekerasan dalam rumah tangga dan sanksi terhadap pelaku kekerasan dalam rumah tangga baik yang dilakukan suami maupun istri. Penelitian ini adalah penelitian normatif, yaitu dengan menelusuri ketentuan-ketentuan hukum baik yang ada dalam al-Quran, hadits, maupun pendapat para fuqaha'. Hasil dari penelitian ini adalah: pertama, setiap perbuatan yang menyebabkan terkuranginya atau hilangnya hak dari masing-masing suami atau istri adalah termasuk kekerasan dalam rumah tangga (KDRT) baik dalam bentuk kekerasan seksual, fisik, psikis, dan finansial. Kedua, Terhadap KDRT yang dilakukan oleh masing-masing suami atau istri hukum Islam memberikan sanksi ('uqubah) berupa hukuman di akhirat (dosa), kaffarat atau ta'zir.

This research is aimed to provide an overview regarding the forms of domestic violence and sanctions against perpetrators of domestic violence both by husbands and wives. This research is normative research by tracing the legal provisions both in the Koran, hadith, and the opinions of the jurists. The results of this study are: first, every action that causes or diminishes the rights of each husband or wife includes domestic violence in the form of sexual, physical, psychological and financial violence. Second, Islamic law gives sanctions ('uqubah) for any domestic violence committed by each husband or wife in the form of punishment in the hereafter (sin), kaffarat or ta'zir.
\end{abstract}

Kata Kunci: kekerasan dalam rumah tangga; hukum Islam; sanksi

\section{Pendahuluan}

Berpasang-pasangan adalah ketetapan Allah SWT. terhadap semua makhluknya sebagaimana difirmankan Allah dalam Qs. al-Dzariyat (51) ayat 49 dan Qs. Yasin ayat 36. Ketetapan ini kemudian melahirkan aturan bahwa berpasang-pasangan antara lakilaki dan perempuan haruslah berada dalam satu ikatan pernikahan sebagaimana sudah diatur dalam hukum Islam. ${ }^{1}$ Salah satu tujuan pernikahan adalah tercapainya kehidupan yang tenteram dan bahagia sebagaimana ditegaskan Allah dalam Qs. al-Rûm (30) ayat

\footnotetext{
${ }^{1}$ Terminologi hukum Islam merujuk kepada salah satu atau ketiga hal berikut: (1) syariat, (2) fiqh, (3) alqanun al-Islami
} 
21. ${ }^{2}$ Salah satu indikator kehidupan yang tenteram dan bahagia dalam rumah tangga adalah masing-masing anggota keluarga, baik suami maupun istri memahami dan melaksanakan hak dan kewajibannya. Ketika hak dan kewajiban ini tidak terlaksana maka yang terjadi adalah terjadinya kekerasan baik secara fisik, psikis, seks, dan ekonomi. Kekerasan inilah yang kemudian merusak ketentraman dan kebahagiaan dalam rumah tangga. Pelanggaran terhadap hak dan kewajiban ini melahirkan satu konsep yang disebut dengan nusyuz, jika terkait dengan hak dan kewajiban suami dan istri.

Islam dengan instrumen hukumnya hadir agar tidak ada satu anggota keluarga menyakiti anggota keluarga lainnya dalam bentuk apapun. Oleh karena itu, hukum Islam kemudian menetapkan sanksi agar siapapun yang hendak melakukan kekerasan bisa tercegah atau kalaupun tidak bisa, maka bisa dihentikan dan diatasi melalui sanksi yang diberikan.Hanya saja, belum adanya kajian yang komprehensif tentang bentukbentuk kekerasan dalam rumah tangga memberikan kesan bahwa hukum Islam abai dalam memberikan perlindungan terhadap anggota keluarga, atau bahkan dalam beberapa kajian, ${ }^{3}$ hukum Islam dianggap menomorduakan atau bersikap tidak adil terhadap perempuan dalam kapasitasnya sebagai istri. Oleh karena itu, kajian yang komprehensif mengenai bentuk-bentuk kekerasan dalam rumah tangga dan sanksinya, baik pelakunya suami maupun istri, menjadi sangat relevan dan penting. Menelusuri bentuk-bentuk kekerasan dalam rumah tangga perspektif hukum Islam juga akan memberikan gambaran yang komprehensif tentang bagaimana hukum Islam memperlakukan setiap anggota keluarga, baik suami maupun istri secara adil dan proporsional.

Kajian tentang kekerasan dalam rumah tangga sudah banyak dilakukan. Seperti tulisan dari Didi Sukardi yang berjudul Kajian Kekerasan Rumah Tangga Perspektif Hukum Islam dan Hukum Positif, ${ }^{4}$ tulisan ini membandingkan konsep kekerasan dalam rumah tangga menurut Kitab Undang-Undang Hukum Pidana (KUHP) dan Hukum Pidana Islam. Kajian lain yang memiliki kesamaan tema adalah tulisan dari Faqiuddin Abdul Kodir yang berjudul Kekerasan dalam Rumah Tangga (KDRT) Perspektif Islam: Kompilasi Awal Teks-Teks hadis Rujukan, ${ }^{5}$ tulisan ini hanya fokus pada persoalan teks hadits tentang pemukulan istri dan sumber-sumber kitab hadits rujukannya. Kedua tulisan tersebut sama sekali tidak membahas tentang bentuk-bentuk kekerasan dalam Islam dan sanksinya.

\footnotetext{
2"Dan di antara tanda-tanda kekuasaan-Nya ialah Dia menciptakan untukmu isteri-isteri dari jenismu sendiri, supaya kamu cenderung dan merasa tenteram kepadanya, dan dijadikan-Nya diantaramu rasa kasih dan sayang. Sesungguhnya pada yang demikian itu benar-benar terdapat tanda-tanda bagi kaum yang berfikir. (Qs. al-Rum (30): 21)

${ }^{3}$ Seperti kajian mengenai hadits-hadits misoginis, misalkan hadits tentang Malaikat melaknat istri yang menolak untuk digauli oleh suaminya. Kajian yang sepotong-sepotong seperti ini memberikan kesan ketidakadilan hukum Islam terhadap perempuan. Padahal pada saat yang sama, hukum Islam memberikan hukuman yang lebih berat kepada suami yang tidak mau menggauli istrinya, seperti dalam kasus zhihar dan ilâ'.

${ }^{4}$ Didi Sukardi, "Kajian Kekerasan Rumah Tangga Perspektif Hukum Islam Dan Hukum Positif," Jurnal Mahkamah 9, no. 1 (2015).

${ }^{5}$ Faqiuddin Abdul Kodir Kodir, "Kekerasan Dalam Rumah Tangga (KDRT) Perspektif Islam: Kompilasi Awal Teks-Teks Hadis Rujukan,” Mahkamah: Jurnal Kajian Hukum Islam 1, no. 1 (2016).
} 


\section{Metode Penelitian}

Penelitian ini adalah penelitian normatif. ${ }^{6}$ Dalam hal ini peneliti melakukan penelusuran pustaka terhadap ketentuan-ketentuan hukum Islam baik yang terdapat di dalam al-Qur'an, hadits, maupun ijtihad para ulama yang terekam dengan baik dalam kitab-kitab fiqh yang terkait dengan bentuk-bentuk kekerasan dalam rumah tangga yang dilakukan oleh suami maupun istri dan sanksi apa yang ditentukan bagi masing-masing pelakunya. Selain al-Qur'an dan kitab-kitab hadits, peneliti juga menggunakan bebrapa kitab yang dijadikan rujukan utama, yaitu: (1) al-Fiqh al-Islami wa Adillatuhu karya Wahbah al-Zuhaili, (2) al-Mufashshal fi Ahkam al-Mar'ah wa al-Bayt al-Muslim karya Abdul Karim Zaydan, (3) al-Fiqh 'Ala Madzahib al-Khamsah karya Muhammad Jawad Mughniyah, (4) Bidayah al-Mujtahid karya Ibnu Rusyd, dan (5) Mauqif al-Islam min Nusyuz al-Zaujayn au Ahadihima karya Nur Hasan Qarut.

\section{Hasil dan Pembahasan \\ Bentuk-Bentuk Kekerasan Suami terhadap Istri dan Sanksinya dalam Hukum Islam}

Klasifikasi kekerasan dalam rumah tangga yang digunakan sebagai acuan adalah kekerasan yang dimaksud dalam Undang-Undang Nomor 23 Tahun 2004 tentang Penghapusan Kekerasan Dalam Rumah Tangga dengan sedikit penyesuaian, yaitu: 1) Kekerasan fisik, yaitu segala bentuk kekerasan yang menimbulkan memar, luka, atau sakit fisik lainnya, seperti memukul, menendang, melukai dan lainnya. 2) Kekerasan psikis, yaitu segala bentuk kekerasan yang melukai perasaan pasangan, seperti mencaci, memaki, menyumpahi, tidak mengajak bicara dan lainnya. 3) Kekerasan seksual, yaitu segala bentuk kekerasan yang menyebabkan pasangan tidak terpenuhi kebutuhan seksualnya, seperti tidak mau diajak berhubungan badan, bersumpah tidak akan menggauli pasangan dan lainnya. 4) Kekerasan ekonomi/finansial. ${ }^{7}$ Yaitu segala bentuk kekerasan yang membuat pasangan tidak mendapatkan hak-hak finansial yang sudah ditentukan oleh hukum Islam, seperti tidak mau menafkahi, tidak mau membayar mahar dan lainnya.

Ada beberapa bentuk kekerasan seksual yang dikenal dalam konteks hukum Islam, antara lain: Pertama, Zhihar. Zhihar adalah ungkapan seorang suami terhadap istrinya: bagiku kamu seperti punggung ibuku (anti 'alayya ka zhahri ummi). ${ }^{8}$ Zhihar yang bermakna punggung, secara khusus digunakan sebagai sebuah ungkapan untuk mengharamkan istri bagi suami, dan tidak menggunakan anggota badan yang lain adalah karena pada umumnya punggung adalah bagian tubuh yang ditunggangi, oleh karena itulah-dalam bahasa Arab-yang ditunggangi (markub) disebut dengan punggung (zhahran), perempuan disamakan dengan punggung karena dia ditunggangi laki-laki. ${ }^{9}$ Namun demikian, bukan berarti penggunaan anggota badan yang lain tidak dianggap zhihar. Maka, jika seorang suami mengatakan kepada istrinya: bagiku kamu seperti perut ibuku, atau seperti kepala ibuku, atau seperti tangan ibuku, atau secara kumulatif: perut, kepala, dan tanganmu seperti punggung ibuku, atau dengan

\footnotetext{
${ }^{6}$ Soerjono Soekanto, Pengantar Penelitian Hukum (Jakarta: UIN Press, 1986), 50.

${ }^{7}$ Pasal 5 UU PKDRT menggunakan istilah penelantaran rumah tangga.

${ }^{8}$ Muhammad bin Idris Al-Syafi'i, Al-Umm, 1st ed., Juz 6 (Dar al-Wafa' Li al-Thiba'ah wa al-Nasyr wa alTauzi', 2001), 697.

${ }^{9}$ Muhammad Ali al-Shabuni, Rawai'u Al-Bayan Tafsiru Ayati Al-Ahkam Min Al-Qur'an, 3rd ed., Juz 2 (Beirut: Muassasah Manahilu al-'Irfan, 1981), 461.
} 
menggunakan ungkapan anggota badan yang lain maka yang demikian juga dinamakan zhihar. ${ }^{10}$

Sanksi terhadap suami yang melakukan zhihar terhadap istrinya adalah sebagaimana firman Allah dalam Qs. al-Mujadalah ayat 3-4: "Orang-orang yang melakukan zhihar kepada isteri mereka, kemudian mereka hendak menarik kembali apa yang mereka ucapkan, maka (wajib atasnya) memerdekakan seorang budak sebelum kedua suami isteri itu bercampur. Demikianlah yang diajarkan kepada kamu, dan Allah Maha mengetahui apa yang kamu kerjakan. Barangsiapa yang tidak mendapatkan (budak), maka (wajib atasnya) berpuasa dua bulan berturut-turut sebelum keduanya bercampur. Maka siapa yang tidak kuasa (wajiblah atasnya) memberi makan enam puluh orang miskin. Demikianlah supaya kamu beriman kepada Allah dan Rasul-Nya. dan Itulah hukum-hukum Allah, dan bagi orang kafir ada siksaan yang sangat pedih.

Pada Ayat tersebut Allah menjelaskan tentang kaffarat bagi suami yang menzhihar istrinya, kaffarat tersebut menurut ijma' ulama, sebagaimana disampaikan alShan'ani dalam subulu al-salam harus dilakukan secara berurutan. ${ }^{11}$ Sehingga suami harus membayar kaffarat berikut secara berurutan sesuai dengan kemampuan yang bersangkutan: 1) Membebaskan budak, 2) Berpuasa dua bulan berturut-turut, 3)Memberi makan enam puluh orang miskin. Kedua: ilâ'.Secara etimologis, ilâ' bermakna sumpah (al-halaf wa al-yamin). ${ }^{12}$ Sedangkan secara terminologis, ada beragam definis dengan redaksi yang sedikit berbeda satu sama lain. Redaksi yang ditawarkan Ibnu Rusyd sepertinya cukup menggambarkan ragam definisi yang ditawarkan oleh para ulama:

$$
\text { بإطلاق. } 13 \text { والإيلاء هو أن يحلف الرجل أن لا يطأ زوجته إما مدّة هي أكثر من أربعة أشهر أو أربعة أشهر أو }
$$

Artinya: "Ila adalah seorang suami yang bersumpah untuk tidak menggauli istrinya dalam jangka waktu lebih dari empat bulan, empat bulan, atau tanpa batasan waktu”.

Dasar hukum dari disyariatkannya ilâ' adalah firman Allah SWT: 'Kepada orangorang yang meng-ilâ' isterinya diberi tangguh empat bulan (lamanya). kemudian jika mereka kembali (kepada isterinya), Maka Sesungguhnya Allah Maha Pengampun lagi Maha Penyayang. Dan jika mereka ber'azam (bertetap hati untuk) talak, Maka Sesungguhnya Allah Maha mendengar lagi Maha mengetahui." (Qs. al-Baqarah (2): 226-227). Pada masa jahiliyah, ilâ' dan juga zhihar adalah salah satu bentuk talak yang digunakan oleh orang-orang Arab untuk menyakiti istrinya, yaitu dengan cara bersumpah untuk tidak menggauli istrinya selama setahun atau lebih, kemudian setelah selesai setahun atau lebih, suami akan mengulangi kembali sumpahnya, dan begitu seterusnya. ${ }^{14}$ Hal tersebut akan membuat istri tersakiti seksual, karena tidak

\footnotetext{
${ }^{10}$ Abu Muhammad Al- Husain bin Mas'ud Al-Baghawi, Tafsir Al-Baghawi: Ma'alim Al-Tanzil, Jilid 8 (Riyadh: Dar Thaybah, 1412), 50.

${ }^{11}$ Muhammad bin Isma'il al-Shan'ani, Subulu Al-Salam Syarh Bulugh Al-Maram, Juz 3 (Riyadh: Maktabah al-Ma'arif li al-Nasyr wa al-Tauzi', 2006), 510.

${ }^{12}$ Wahbah al-Zuhaili, Al-Fiqh Al-Islami Wa Adillatuhu, 2nd ed., Juz 7 (Damaskus: Dar al-Fikr, 1985), 535.

${ }^{13}$ Ibnu Rusyd, Bidayatul Mujtahid Wa Nihayah Al-Muqtashid (Beirut: Dar al-Kutub al-Ilmiyah, 2010), 515.

${ }^{14}$ al-Zuhaili, Al-Fiqh Al-Islami Wa Adillatuhu, 1985, 535.
} 
mendapatkan hak-hak seksualnya dari suami. Menurut Hanafiyah, konsekuensi hukum ilâ' ada dua, yaitu sanksi ukhrawi dan sanksi duniawi. Sanksi ukhrawi berupa dosa hingga suami menarik kembali sumpahnya, sebagaimana firman Allah:"...kemudian jika mereka kembali (kepada isterinya), Maka Sesungguhnya Allah Maha Pengampun lagi Maha Penyayang" (Qs. al-baqarah (2): 226). Menurut Hanafiyah hukum dari ilâ' adalah makruh tahrim. ${ }^{15}$ Selain sanksi Ukhrawi tersebut, ada sanksi hukum yang bersifat duniawi, yaitu suami diberikan dua pilihan, yaitu: (1) membatalkan sumpahnya dengan membayar kaffarat dan menggauli istrinya, atau (2) menceraikan istrinya.

Kaffarat sumpah karena ilâ' dilakukan dengan menggauli istrinya dan memberi makan sepuluh orang miskin atau memberi pakaian kepada mereka, atau membebaskan budak, atau berpuasa selama tiga hari. Ketentuan tersebut didasarkan pada firman Allah dalam Qs. Al-Maidah (5): 89 yaitu : "Allah tidak menghukum kamu disebabkan sumpah-sumpahmu yang tidak dimaksud (untuk bersumpah), tetapi Dia menghukum kamu disebabkan sumpah-sumpah yang kamu sengaja, Maka kaffarat (melanggar) sumpah itu, ialah memberi Makan sepuluh orang miskin, Yaitu dari makanan yang biasa kamu berikan kepada keluargamu, atau memberi pakaian kepada mereka atau memerdekakan seorang budak. barang siapa tidak sanggup melakukan yang demikian, Maka kaffaratnya puasa selama tiga hari. yang demikian itu adalah kaffarat sumpahsumpahmu bila kamu bersumpah (dan kamu langgar). dan jagalah sumpahmu. Demikianlah Allah menerangkan kepadamu hukum-hukum-Nya agar kamu bersyukur (kepada-Nya)".

Jika suami tidak mau kembali kepada istrinya dengan cara menggauli dan membayar kaffarat sumpah, maka alternatif sanksi hukum yang kedua bagi suami adalah menceraikannya. Para ulama berbeda pendapat mengenai suami yang menolak untuk menggauli atau menceraikan istrinya. Hanafi menyatakan bahwa otomatis jatuh talak bain tanpa harus diajukan lagi perkaranya ke hakim, atau — kalau tidak begitusuami harus menalak istrinya. Maliki, Syafi'i, dan Hambali mengatakan bahwa apabila lewat empat bulan, dan dia tidak mencampuri isterinya, maka hal tersebut diajukan kepada hakim, supaya hakim menyuruh laki-laki itu mencampuri istrinya. Kalau menolak, hakim memerintahkannya untuk menjatuhkan talak, dan kalau dia juga menolak, hakimlah yang menjatuhkan talaknya, dan talaknya adalah talak raj' $\hat{\imath}^{16}$ Penjelasan yang berbeda dikemukakan oleh Imamiyah yang menyatakan bahwa apabila waktunya telah lewat empat bulan, dan si suami tidak pula mencampuri istrinya, maka bila istrinya masih bisa menahan diri dan rela, itu adalah haknya, tanpa ada hak bagi seseorang untuk menentangnya. Tetapi bila sudah tidak bisa menahan diri, ia mengajukan persoalannya kepada hakim dan sesudah lewat masa empat bulan berikutnya, ${ }^{17}$ hakim harus memaksa suami untuk rujuk atau talak. Kalau dia menolak, dia harus ditekan dan dimasukkan tahanan sampai dia menjatuhkan salah satu diantara dua alternatif tadi. Hakim tidak berhak menjatuhkan talak secara paksa. ${ }^{18}$

\footnotetext{
${ }^{15}$ al-Zuhaili, 546.

${ }^{16}$ Muhammad Jawad Mughniyah, Fiqih Lima Mazhab, trans. Masykur A.B., Afif Muhammad, Idrus AlKaff, 28th ed. (Jakarta: Penerbit Lentera, 2013), 499.

${ }^{17}$ Mayoritas ulama madzhab Imamiyah mengatakan: hakim memberi tangguh empat bulan kepada suami sejak urusan itu diajukan kepadanya, dan tidak dari saat suami tersebut menyatakan sumpahnya. Dalam footnote. Muhammad Jawad Mughniyah, Fiqih Lima Madzhab, 499.

${ }^{18}$ Mughniyah, Fiqih Lima Mazhab, 499.
} 
Ketiga, Sodomi (Anal Sex) atau menggauli istri melalui dubur. Ibnu Taimiyah ${ }^{19}$ menegaskan bahwa berhubungan badan melalui dubur (al-wath'u fi al-dubur) hukumnya adalah haram, berdasarkan al-Qur'an, Sunnah, dan juga pendapat jumhur ulama baik sahabat, tabiin, dan lainnya. Allah berfirman dalam Qs. Al-Baqarah (2) ayat 223: "Isteri-isterimu adalah (seperti) tanah tempat kamu bercocok tanam, maka datangilah tanah tempat bercocok-tanammu itu bagaimana saja kamu kehendaki". Kata al-Harts (حَرْنُ) adalah tempat bercocok tanam yang mempunyai pengertian bahwa anak ditanam di farji dan bukannya di dubur sesuai dengan ketentuan hadis Rasulullah SAW yang menyatakan:

$$
\text { إن الله لا يستحي من الحق لا تأتوا النساء في حشوشهن }
$$

Artinya: "Sesungguhnya Allah tidak malu menyatakan kebenaran, jangan menggauli istri di dubur mereka."

Menurut madzhab Hanafiyah, Syafiiyah, dan Hanabilah hukum menggauli istri melalui dubur adalah haram dan tidak ada perselisihan mengenai hal tersebut. Malikiyah menurut pendapat yang zhahir juga mengharamkannya, meskipun ada sebagian diantara mereka dalam riwayat yang lain yang tidak mengharamkan. ${ }^{20}$ Ulama Madhhab empat, dan Zaidiyah menyatakan bahwa seorang suami yang menggauli istrinya di dubur maka dia dikenakan hukuman ta'zir dan bukan hudud. ${ }^{21}$ Dalam hadits terdapat banyak ketentuan yang menegaskan tentang haramnya berhubungan badan dengan istri melalui dubur, diantaranya:

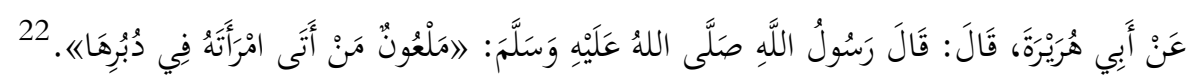

Artinya: "Dari Abu Hurairah ra bahwasanya Rasulullah saw bersabda: terlaknat suami yang menggauli istrinya di duburnya".

Ibnu Taimiyah dalam majmu' al-fatawa menjelaskan tentang sanksi hukum bagi suami yang menggauli istrinya di dubur:

$$
\begin{aligned}
& \text { وأباح للرجل أن يأتي امرأته من جميع جهاته، لكن في الفرج خاصة. ومتى وطئها في الدبر وطاوعته عزرا }
\end{aligned}
$$

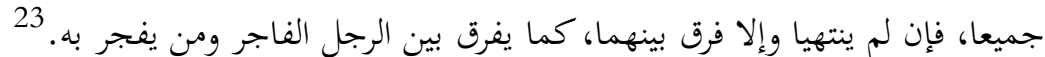

Artinya: "Seorang suami boleh menggauli istrinya dari arah mana saja dia mau, tapi hanya boleh dimasukkan kedalam farji. Jika suami tersebut menggauli istrinya di dubur dan terbiasa melakukan hak tersebut, maka suami istri tersebut dikenai hukum ta'zir, jika tidak juga berhenti maka keduanya diceraikan, sebagaimana pelaku maksiat dipisahkan dengan orang yang diajak melakukan perbuatan maksiat."

\footnotetext{
${ }^{19}$ Ahmad Ibnu Taimiyah, Majmu’ Al-Fatawa, Juz 32 (Madinah: Mujamma' al-Malik Fahd Li Thiba'ah alMushhaf al-Syarif, 2004), 267-68.

${ }^{20}$ Taimiyah, 268.

${ }^{21}$ Abdul Karim Zaidan, Al-Mufashshal Fi Ahkam Al-Mar'ah Wa Al-Bayt Al-Muslim Fi Al-Syari'ah AlIslamiyah, Juz 5 (Beirut: Muassasah al-Risalah, 1993), 450.

${ }^{22}$ Abu Daud Sulaiman bin al-Asy'ats al-Sijistani, Sunan Abi Daud (Riyadh: Maktabah al-Ma'arif li alNasyr wa al-Tauzi', 1417), 375.

${ }^{23}$ Taimiyah, Majmu' Al-Fatawa, 267.
} 
Keempat, Tidak Menggauli Istri. Berhubungan badan (al-wath'u) adalah hak istri dan kewajiban bagi suami. Ibnu Qudamah dalam al-Mughni menegaskan tentang hak seorang istri untuk digauli suaminya:

$$
\text { والوطء واجب على الرجل - أي على الزوج بأن يجامع امرأته - إذا لم يكن له عذر، وبه قال مالك. } 24
$$

"Wajib bagi suami untuk menggauli istrinya, jika suami tidak ada udzur, pendapat ini juga dinyatakan oleh Imam Malik."

Dalil yang dikemukakan oleh para ulama tentang kewajiban suami untuk menggauli istrinya adalah: ${ }^{25}$ 1) Imam al-Jashshash menyatakan bahwa seorang suami wajib untuk menggauli istri berdasarkan ayat "fatadzaruha kal mu'allaqah" (Qs. alNisa'(4): 129). Menurutnya, seorang perempuan yang bersuami tetapi tidak digauli, maka seakan-akan dia tidak bersuami. 2) Teguran Rasulullah SAW kepada 'Abdullah: "Dari Abdullah bin 'Amr bin al-'Ash bahwasanya Rasulullah saw bersabda: wahai Abdullah benarkah yang telah disampaikan kepadaku bahwa kamu berpuasa di siang hari dan shalat sepanjang malam? Aku (Abdullah) menjawab: benar wahai Rasulullah. Kemudian Rasulullah menegurnya: Jangan lakukan itu wahai Abdullah, berpuasalah tapi berbukalah, bangun dan tidurlah, karena sesungguhnya tubuh, mata, dan istrimu, mempunyai hak atasmu." ${ }^{26}$ Ibnu Hajar al-"Asqalani dalam fath al-bari menjelaskan maksud dari hadits tersebut dengan menyatakan: tidak seharusnya seorang suami berlebihan dalam ibadah sehingga dia menjadi tidak memiliki kekuatan untuk menunaikan kewajibannya berupa jima' atau bekerja. Para ulama berbeda pendapat mengenai suami yang tidak mau menggauli istrinya, menurut Imam Malik suami dipaksa untuk menggauli istrinya atau keduanya dipisahkan (yufarriqu baynahuma), pendapat yang senada disampaikan oleh Imam Ahmad. Pendapat yang masyhur di kalangan Syafiiyah bahwa suami tidak wajib menggauli istrinya, pendapat lain dari Syafiiyah menyatakan bahwa yang wajib adalah sekali saja dalam pernikahan, menurut sebagian ulama salaf sekali dalam empat malam, sebagian lainnya menyatakan wajib sekali pada setiap masa suci istri. ${ }^{27} 3$ ) Pernikahan disyariatkan untuk kemaslahatan suami-istri, dan agar mencegah mudharat yang timbul dari keduanya, khususnya mudharat syahwat dari keduanya. Untuk menghindari hal tersebut adalah dengan berhubungan badan antara suami dan istri. Oleh karena itulah berhubungan badan yang bisa menghindarkan diri dari bahaya syahwat menjadi wajib hukumnya. 4) Seandainya istri tidak mempunyai hak untuk digauli, maka suami tidak akan diwajibkan untuk meminta izin kepada istri ketika hendak melakukan 'azl. 5) Umar bin Khatthab menyetujui keputusan Ka'b bin Siwar yang mengharuskan seorang suami untuk bermalam di rumah istrinya sekali dalam setiap empat malam. Ibnu Qudamah menyatakan bahwa keputusan ini sudah tersebar luas dan tidak seorang pun yang mengingkarinya, sehingga ini menjadi ijma'. Abdul Karim Zaydan menambahkan bahwa bermalam bersama istri biasanya menyebabkan hubungan badan diantara keduanya.

\footnotetext{
${ }^{24}$ Abdul Karim Zaidan, Al-Mufashshal Fi Ahkam Al-Mar'ah Wa Al-Bayt Al-Muslim Fi Al-Syari'ah AlIslamiyah, Juz 7 (Beirut: Muassasah al-Risalah, 1993), 239.

${ }^{25}$ Zaidan, 239-40.

${ }^{26}$ Abu Abdillah Muhammad bin Ismail al-Bukhari, Shahih Al-Bukhari (Beirut: Dar Ibnu Katsir, 2002), 1326.

${ }^{27}$ Ahmad bin 'Ali Ibnu Hajar, Fathul Bari, Juz 9 (Riyadh: Maktabah al-Salafiyah, 1379), 299.
} 
Para ulama berbeda pendapat tentang jangka waktu kewajiban suami untuk menggauli istrinya: ${ }^{28}$ 1) Menurut Imam Syafi'î satu kali dalam pernikahan, 2) menurut Hanabilah empat bulan sekali, sebagaimana jangka waktu berlakunya hukum ilâ', 3) menurut Ibnu Hazm satu kali pada setiap masa suci istri berdasarkan firman Allah: Faidza tathahharna fa'tuhunna min haitsu amarakumullah, 4) menurut Imam alGhazali satu kali dalam setiap empat malam. Ulama sepakat bahwa istri mempunyai hak untuk digauli, meskipun ada perbedaan pendapat tentang jangka waktu kewajiban suami untuk menggauli. Ketika istri tidak mendapatkan haknya untuk digauli maka hal tersebut akan menyebabkan istri tersakiti secara seksual. Dari penjelasan diatas dapat disimpulkan bahwa suami yang tidak menggauli istrinya mendapatkan dua sanksi, yaitu: 1) Dosa, sebagaimana dijelaskan bahwa hukumnya wajib bagi suami untuk menggauli istrinya, sehingga bagi yang tidak melakukannya terkena dosa, 2) Imam Malik dan Imam Ahmad sebagaimana dikutip Ibnu Hajar dalam fath al-bari bahwa suami harus dipaksa (ilzam) untuk menggauli istrinya, dan jika tetap tidak mau maka keduanya dipisahkan.

Bentuk kekerasan fisik dalam rumah tangga yang dilakukan suami terhadap istrinya bisa berupa: 1) memukul tanpa sebab atau, 2) memukul melebihi batas yang diperbolehkan oleh syariat. Islam melarang seorang suami memukul istrinya tanpa sebab dan alasan yang dibenarkan oleh syariat. Argumentasi hukum terhadap larangan ini adalah mafhum mukhalafah dari firman Allah:“...Wanita-wanita yang kamu khawatirkan nusyuznya, Maka nasehatilah mereka dan pisahkanlah mereka di tempat tidur mereka, dan pukullah mereka..." (Qs. An-Nisa'(4): 34). Ayat ini menunjukkan bahwa kebolehan memukul dan pisah ranjang hanya terhadap seorang istri yang melakukan nusyuz, sehingga logika mafhum mukhalafah-nya adalah terhadap istri yang tidak nusyuz tidak boleh memukul dan pisah ranjang. ${ }^{29}$ Argumen ini dikuatkan dengan lanjutan radaksi pada ayat yang sama yang menyatakan: “...Kemudian jika mereka mentaatimu, Maka janganlah kamu mencari-cari jalan untuk menyusahkannya..." (Qs. An-Nisa' (4): 34).

Selain itu, ada banyak hadits dari Rasulullah yang melarang seorang suami untuk memukul istrinya, diantaranya:

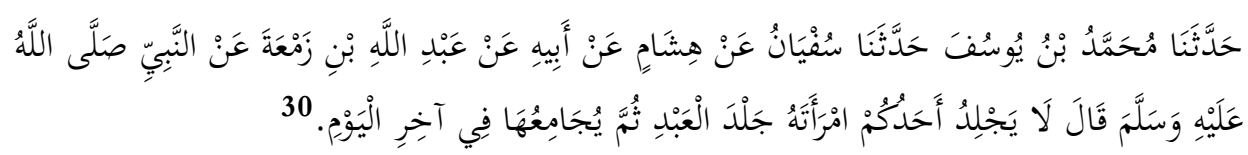

Artinya: "Muhammad bin Yusuf menceritakan kepada kami, telah menceritakan kepada kami Sufyan dari Hisyam dari bapaknya dari Abdullah bin Zam'ah dari Nabi shallallahu 'alaihi wasallam, kalian memukul isterinya, seperti ia memukul seorang budak, namun saat hari memasuki waktu senja ia pun menggaulinya"

Seorang suami yang memukul istrinya bukan karena istrinya nusyuz, maka sebenarnya dia telah melanggar asas dan kewajibannya untuk ber-mua'syarah bil ma'ruf dengan istrinya. Selain memang banyak hadits yang melarang suami memukul

\footnotetext{
${ }^{28}$ Wahbah al-Zuhaili, Al-Fiqh al-Islami wa Adillatuhu, Juz IX, 329-330.; Abdul Karim Zaydan, alMufashshal fi Ahkam al-Mar'ah, Juz VII, 241.

${ }^{29}$ Nur Hasan Qarut, Mauqifu Al-Islam Min Nusyuz Al-Zaujayn Aw Ahadihima Wama Yatba'u Dzalika Min Ahkamin (Dirasah Muqaranah) (Mekkah: Jami'atu Ummul Qura, 1995), 211.

${ }^{30}$ al-Bukhari, Shahih Al-Bukhari, 1327.
} 
istrinya. Sehingga memukul tanpa adanya sebab, seperti bukan karena istri nusyuz atau memukul melebihi batas adalah salah satu bentuk kekerasan dalam rumah tangga. Terhadap suami yang memukul istrinya bukan karena nusyuz dan melebihi batas yang diperbolehkan, para ulama berbeda pendapat mengenai sanksi yang bisa dikenakan terhadap suami: 1) Hanafiyah dan Syafiiyah menyatakan bahwa seorang istri hendaknya mengajukan perkara pemukulan tersebut kepada hakim. Dan hakim mengambil tindakan yang pertama yaitu menasehati dan melarangnya untuk memukul istrinya, jika suami tersebut termasuk orang yang memiliki akhlak dan kata-kata yang baik, maka hakim hendaknya menasehatinya dengan lemah lembut, tetapi jika suami tersebut termasuk orang yang berwatak kasar maka hakim menasehatinya dengan ancaman. Jika kemudian, suami tersebut mengulangi lagi memukul istrinya, maka hakim menjatuhkan hukuman ta'zir. 2) Imam al-Ghazali menyatakan bahwa jika suami memukul dan menyakiti istrinya, maka keduanya dipisahkan hingga hubungan keduanya menjadi normal kembali. 3) Malikiyah menyatakan bahwa jika seorang suami memukul istrinya bukan karena nusyuz, maka hakim menghukum suami tersebut dengan ta'zir atau jika mau, istri boleh meminta kompensasi yang harus dibayarkan suami sesuai dengan keputusan hakim. Sebagian Malikiyah lainnya menyatakan bahwa suami tersebut harus dipenjara. 4) Zhahiriyah menyatakan terhadap suami yang memukul istrinya tanpa sebab, maka sanksi hukumnya adalah Qishash, sebagaimana firman Allah dalam Qs. alBaqarah (2) ayat $194 .^{31}$

Kekerasan psikis juga dikenal dalam khazanah hukum Islam. Termasuk dalam bentuk kekerasan psikis antaralain: Pertama, Bersikap Tidak Adil Terhadap Istri dalam Pernikahan Poligini. Seorang suami yang memiliki lebih dari satu istri, maka diwajibkan baginya untuk berlaku adil terhadap istri-istrinya. Kewajiban berlaku adil ini berdasarkan firman Allah dalam Qs. al-Nisa' (4) ayat 3, 19, dan 129. Rasulullah Saw. memperingatkan bagi suami yang berlaku tidak adil terhadap istrinya dengan menyatakan:

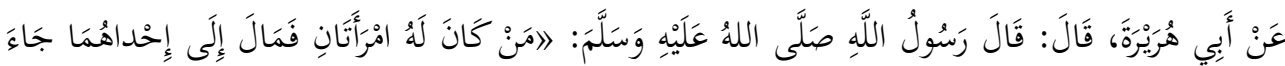

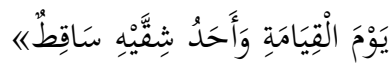

Artinya: "Dari Abu Hurairah bahwasanya Rasulullah saw bersabda: Barangsiapa memiliki dua istri dan dia condong kepada alah satu istrinya, maka pada hari kiamat kelak bahunya akan miring sebelah." (HR. Abu Daud)

Adanya ancaman bahwa suami yang tidak adil berdasarkan hadits tersebut mengindikasikan bahwa perbuatan tersebut adalah dosa yang akan ditanggung di akhirat nanti. Selain itu tidak menunaikan hak istri untuk digilir dan diberi nafkah jelas adalah tindakan kekerasan psikis yang dilakukan oleh suami terhadap istri. Selain ancaman sanksi di akhirat nanti, para ulama berbeda pendapat mengenai sanksi duniawi bagi suami yang bersikap tidak adil terhadap istri-istrinya: ${ }^{32}$ 1) Hanafiyah menyatakan bahwa jika seorang suami tidak menggilir (al-qasam) istrinya, dimana dia hanya tinggal dengan salah seorang istrinya dan mengabaikan istri yang lain, maka hendaknya istri mengajukan perkara tersebut kepada hakim. Yang pertama dilakukan oleh hakim adalah

\footnotetext{
${ }^{31}$ Qarut, Mauqifu Al-Islam Min Nusyuz Al-Zaujayn Aw Ahadihima Wama Yatba'u Dzalika Min Ahkamin (Dirasah Muqaranah), 214-15.

${ }^{32}$ Qarut, 295-96.
} 
menyuruhnya untuk berbuat adil terhadap istri-istrinya, tapi suami tidak bisa dituntut yang telah lalu, tapi perbuatan yang telah lalu tersebut tetap dihukumi dosa. Jika suami tetap tidak berubah setelah diperingatkan dan dinasehati, maka hakim menjatuhkan sanksi ta'zir untuk suami tersebut, tetapi bentuk ta'zir-nya haruslah berupa pukulan (dharb) dan tidak boleh dipenjara, karena pemenjaraan akan menghilangkan hak istri untuk digilir. ${ }^{33}$ 2) Malikiyah menyatakan bahwa jika seorang suami tidak menunaikan hak-hak istrinya, dan istrinya tidak ingin pisah dengan suaminya tersebut, maka hakim memperingatkan dan menasehatinya, dan jika terulang kembali maka hakim mendidiknya, dan jika apa yang dilakukan suami menyebabkan kemudharatan dan si istri ingin bercerai dengan suaminya, maka hakim menceraikan keduanya karena dharar. ${ }^{34}$ 3) Syafiiyah menyatakan bahwa jika seorang suami tidak menunaikan hak-hak istrinya, seperti giliran dan nafkah, maka hakim memaksanya untuk menunaikan hakhak istrinya tersebut. Jika suami mengulangi perbuatannya tersebut, dan istri meminta agar suaminya dihukum dengan ta'zir, maka hakim menjatuhkan hukuman ta'zir kepada suaminya. Jika suami mengulangi kembali setelah diberi hukuman ta'zir, maka hakim memisahkan keduanya, hingga hakim yakin bahwa suami tersebut bisa berlaku adil terhadap istrinya. 4) Hanabilah. Secara umum, Hanabilah sependapat dengan Malikiyah. Jika seorang suami tidak menggilir salah satu istrinya pada hari dimana istri tersebut mendapat giliran, maka hakim boleh menceraikan (yufarriq) keduanya berdasarkan permintaan istri. Hanabilah juga menyatakan bahwa hak yang seperti ini juga dimiliki oleh seorang istri yang tidak memiliki madu, istri tersebut punya hak untuk dibersamai oleh suaminya minimal satu kali dalam empat malam.

Kedua, mencaci dan memaki istri. Terdapat ketentuan al-Quran dan hadits yang melarang seorang muslim untuk mencaci dan memaki muslim lainnya, lebih-lebih istrinya sendiri. Dalam Qs. al-Hujurat (49) ayat 11 Allah berfirman, yang artinya: “...Dan janganlah suka mencela dirimu sendiri dan jangan memanggil dengan gelaran yang mengandung ejekan. Seburuk-buruk panggilan adalah (panggilan) yang buruk sesudah iman dan barangsiapa yang tidak bertobat, maka mereka itulah orang-orang yang zalim". Sementara itu dalam sebuah hadits, Rasulullah saw bersabda:

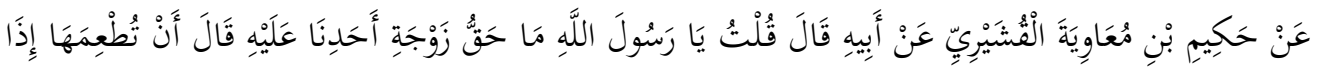

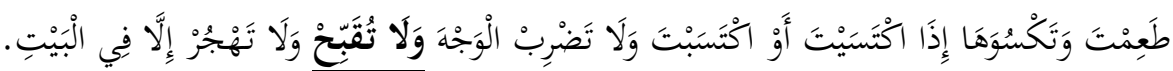

Artinya: "Dari Hakim bin Muawiyah al-Qusyairi dari ayahnya yang bertanya kepada Rasulullah saw: Wahai Rasulullah apakah hak istri kepada kami? Rasulullah menjawab: kamu memberinya makan saat kamu makan, memberinya pakaian, jangan memukul wajahnya, jangan mencaci maki, dan jangan pisah ranjang dengan istrinya kecuali di rumah". (HR. Abu Daud)

Seorang suami yang mencaci dan memaki istrinya jelas telah melanggar kewajibannya untuk memperlakukan istrinya dengan baik (al-mu'asyarah bil ma'ruf). Selain memang mencaci dan memaki dilarang dalam Islam. Oleh karena itu, perbuatan mencaci dan memaki adalah salah satu bentuk kekerasan verbal dan psikis terhadap istri. Sanksi hukum bagi suami yang mencaci dan memaki istrinya diperselisihkan oleh para ulama: 1) Jumhur Ulama yang terdiri dari ulama Hanafiyah, Syafiiyah, Hanabilah,

\footnotetext{
${ }^{33}$ Ibnu Nujaim, Al-Bahru al-Raiq Syarh Kanzu al-Daqaiq, Juz III, 235.; Al-Uzajandi, Fatawa Qadhikhan, Juz I, 439. Sebagaimana dikutip Nur Hasan Qarut, Mauqiful Islam min Nusyuz al-Zaujayn, 295.

${ }^{34}$ Mawahib al-Jalil, Juz IV, 16.; Minah al-Jalil, juz II, 177-178. Sebagaimana dikutip Nur Hasan Qarut, Mauqiful Islam min Nusyuz, al-Zaujayn, 296.
} 
dan Zhahiriyah menyatakan bahwa jika seorang suami menyakiti istrinya, baik memukul atau mencaci, baik hakim memperingatkan suami tersebut untuk menghentikan perbuatan tercela tersebut, jika diulangi maka dia dikenakan hukuman ta'zir. 2) Malikiyah, menurut ulama malikiyah, jika suami terbukti menyakiti istrinya, seprti dicaci dan dimaki, atau pisah ranjang tanpa ada sebab, dan persoalan tersebut diajukan kepada hakim, maka hakim berhak untuk memperingatkannya, jika diulangi maka hakim bisa memberikan hukuman ta'zir. Tetapi jika istri ingin agar diceraikan, maka hakim bisa menceraikan keduanya dengan talak satu bain. ${ }^{35}$

Adapun bentuk-bentuk kekerasan financial yaitu: Pertama, tidak membayar mahar. Memberikan mahar kepada istri hukumnya adalah wajib, sebagaimana firman Allah: "Berikanlah maskawin (mahar) kepada wanita (yang kamu nikahi) sebagai pemberian dengan penuh kerelaan..." (Qs. al-Nisa'(4): 4). Dalam beberapa riwayat Rasulullah memperingatkan suami yang tidak mau membayar mahar kepada istrinya:"Dari Shuhaib bin sinan berkata: saya mendengar Rasulullah saw bersabda: barangsiapa memberikan mahar kepada seorang perempuan, dan Allah mengetahui bahwa dia tidak ada niat untuk membayarnya, dia menipu isterinya dengan nama Allah, dia menghalalkan farji istrinya dengan cara yang batil, maka dia akan bertemu dengan Allah kelak di hari kiamat dalam keadaan berzina. Dan barangsiapa berhutang, dan Allah tahu bahwa dia tidak ada niatan untuk melunasinya, dia menipunya dengan nama Allah, dia mendapatkan uang dengan cara yang batil, kelak di hari kiamat dia akan bertemu dengan Allah sebagai pencuri." 36

Mahar adalah hak istri yang harus dibayar oleh suami. Ketika suami tidak mau membayar mahar yang harusnya dibayar, maka suami tersebut sebenarnya berbuat aniaya terhadap istrinya, dan ini merupakan salah satu bentuk kekerasan finansial yang dilakukan suami terhadap istrinya. Sanksi hukum bagi suami yang tidak mau membayar mahar ada dua, yaitu: 1) Istri boleh menolak untuk digauli dan diajak bepergian. Jumhur ulama, yaitu Hanafiyah, Malikiyah, Syafiiyah, dan Hanabilah menyatakan bahwa istri boleh menolak untuk digauli dan diajak bepergian jika suami tidak mau membayar mahar yang sudah disepakati, dan penolakan istri tersebut tidak bisa dikategorikan sebagai nusyuz. Ulama Hanabilah memberikan catatan bahwa penolakan tersebut hanya bisa dilakukan jika istri belum digauli, tapi jika istri sudah digauli, maka istri tidak punya hak untuk digauli. Pendapat berbeda dikemukakan oleh ulama Zhahiriyah yang menyatakan bahwa sejak akad nikah maka keduanya menjadi halal untuk berhubungan badan, jika ada yang menyatakan bahwa istri boleh menolak untuk digauli jika suami belum membayar mahar, maka orang tersebut telah memisahkan keduanya tanpa berlandaskan kepada al-Quran dan sunnah Rasulullah. ${ }^{37}$ 2) Istri boleh meminta fasakh. Para berbeda pendapat mengenai hak istri untuk meminta fasakh jika suami tidak mau membayar mahar: a) Zhahiriyah, Hanafiyah dan salah satu pendapat Imam Syafii. Menurut mereka, istri tidak memiliki hak untuk meminta fasakh karena suami menolak untuk membayar mahar. b) Hanabilah dan salah satu pendapat Syafiiyah. Menurut Hanabilah dan salah satu pendapat Syafiiyah, seorang istri boleh meminta fasakh, baik sudah dukhul atau belum. c) Malikiyah dan pendapat yang zhahir dari Syafiiyah.

\footnotetext{
${ }^{35}$ Qarut, Mauqifu Al-Islam Min Nusyuz, Al-Zaujayn Aw Ahadihima Wama Yatba'u Dzalika Min Ahkamin (Dirasah Muqaranah), 299-301.

${ }^{36}$ Abu Bakr Abdullah bin Muhammad bin Abi Syaibah, Musnad Ibnu Abi Syaibah, Jilid 1 (Riyadh: Dar al-Wathan, 1997), 323.

${ }^{37}$ Qarut, Mauqifu Al-Islam Min Nusyuz Al-Zaujayn Aw Ahadihima Wama Yatba'u Dzalika Min Ahkamin (Dirasah Muqaranah), 271.
} 
Menurut ulama Malikiyah dan pendapat yang zhahir dari Syafiiyah, istri boleh meminta fasakh jika belum dukhul, tetapi jika sudah berhubungan badan, maka istri tidak bisa meminta fasakh. ${ }^{38}$

Kedua, Tidak Mau Memberi Nafkah Kepada Istri. Suami yang tidak mau memberikan nafkah kepada istrinya, maka dia sebenarnya dia tidak melaksanakan kewajibannya untuk menafkahi istrinya, oleh karenanya tindakan ini bisa dikategorikan sebagai kekerasan finansial suami terhadap istri, karena pada saat itu istri terhadap dari mendapatkan hak-hak finansialnya. Suami yang tidak mau menafkahi istrinya berdosa karena tidak melaksanakan salah satu kewajibannya yaitu menafkahi. Selain itu konsekuensi hukum bagi suami yang tidak mau menafkahi adalah: 1) Para ulama sepakat bahwa jika persoalan tersebut diajukan ke pengadilan dan diputuskan bahwa nafkah yang telah terlewat harus dibayar, maka suami memiliki hutang nafkah yang harus dibayarkan kepada istri. ${ }^{39}$ 2) Istri boleh mengambil harta suaminya tanpa sepengetahuannya secukupnya, sebagaimana sabda Rasulullah SAW dalam riwayat Abu Daud dalam kitabnya: "Dari Aisyah bahwasanya Hindun Ibu dari Muawiyah datang kepada Rasulullah saw dan berkata: sesungguhnya Abu Sufyan adalah suami yang pelit dan kikir, dia tidak memberikan nafkah yang cukup untukku dan anak-anakku, apakah aku berdosa jika mengambil sebagian harta Abu Sufyan (tanpa sepengetahuannya)? Rasulullah kemudian menjawab: Ambillah sebagian dari hartanya untuk mencukupimu dan anakmu dengan cara yang ma'ruf."3) Menurut Imam Malik dalam sebuah riwayat, Imam Syafii dalam salah satu dari dua pendapatnya, Imam Ahmad dalam salah satu dari dua riwayatnya, al-Kharqi dan Zadiyah menyatakan bahwa Hakim boleh memenjarakan suami hingga dia mau membayar nafkah kepada istrinya. 4) Imam Malik dalam salah satu pendapatnya menyatakan bahwa suami yang tidak mau membayar nafkah dan dia tidak memiliki harta yang terlihat dan pada saat yang sama istrinya meminta firaq maka hakim langsung menceraikan keduanya tanpa perlu memberi waktu kepada suaminya. 5) Jumhur ulama dari kalangan Hanafiyah, Hanabilah, dan salah satu pendapat yang ashah dari Imam Syafii menyatakan bahwa istri berhak menolak untuk digauli oleh suaminya, dan istri boleh keluar rumah untuk bekerja meskipun tidak diizinkan oleh suaminya. ${ }^{40}$

Ketiga, Talak Firar. Talak firar (طلاقالفرار) atau thalaq al-maridh maradhul maut, yaitu talak bain yang dilakukan oleh suami suami yang sedang dalam keadaan sakit menjelang meninggal, dengan tujuan agar istri tidak mendapatkan warisan dari suaminya tersebut. ${ }^{41}$ Talak firar adalah salah satu bentuk kekerasan finansial suami terhadap istrinya, karena tujuan dari perceraian tersebut adalah menghilangkan hak waris istri dari suami yang mentalak. Para ulama sepakat tentang jatuhnya talak yang dilakukan oleh suami yang sedang sakit menjelang ajal. Hanya saja, para ulama berbeda pendapat mengenai hak waris istri yang ditalak bain tersebut jika suaminya meninggal. Para ulama terbagi menjadi tiga kelompok, yaitu: ${ }^{42}$ 1) Ulama Hanafiyah, Sufyan. AlLaits, al-Auza'i, Ahmad bin Hambal dalam salah satu riwayatnya, dan al-Syafii dalam qaul qadim-nya menyatakan bahwa wanita tersebut mewarisi suaminya selama suaminya meninggal dalam masa iddah. 2) Imam Ahmad dalam pendapatnya yang

\footnotetext{
${ }^{38}$ Qarut, 272-73.

${ }^{39}$ Qarut, 202.

${ }^{40}$ Qarut, 202-9.

${ }^{41}$ Wahbah al-Zuhaili, Al-Figh Al-Islami Wa Adillatuhu, 2nd ed., 9 (Damaskus: Dar al-Fikr, 1985), 531.

${ }^{42}$ Muhammad 'Athsyan 'Alaiwi, "Hukmu Thalaq al-Maridh Maradhu al-Maut," Majalah al-Fath. Volume ke-22 (2005), 168-170.
} 
masyhur, Abi Layla, Ruwaih dari Abu Hanifah, dan Syafiiyah dalam salah satu pendapatnya menyatakan bahwa wanita tersebut tetap berhak mewarisi suaminya selama istrinya tersebut belum menikah. 3) Malikiyah dan Syafiiyah dalam salah satu pendapatnya menyatakan bahwa istri berhak mewarisi suaminya baik ketika iddah atau sesudah iddah, baik istri tersebut belum menikah atau sudah menikah.

\section{Bentuk-Bentuk Kekerasan Istri terhadap Suami dan Sanksinya dalam Hukum Islam.}

Sebagaimana terdapat bentuk-bentuk kekerasan yang dilakukan suami, terdapat pula bentuk-bentuk kekerasan yang dilakukan oleh istri yang antara lain meliputi kekerasan seksual, psikis dan finansial. Kekerasan seksual yaitu: Pertama, menolak ajakan suami untuk berjimak tanpa alasan yang syar'i. Dalam hal ini Rasulullah SAW bersabda:

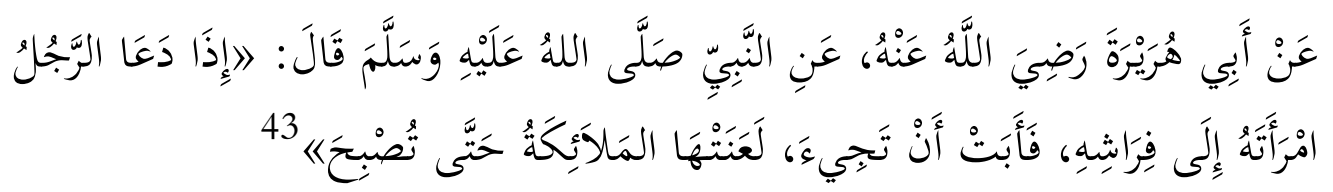

Artinya: "Dari Abu Hurairah bahwasanya Rasulullah saw bersabda: jika seorang suami mengajak istrinya untuk berhubungan badan, kemudian istrinya menolak, maka dia dilaknat malaikat hingga pagi."

Hadis tersebut mengindikasikan bahwa penolakan istri untuk berhubungan badan dengan suaminya hukumnya adalah haram. Terdapat beberapa kondisi seorang istri boleh menolak digauli oleh suaminya, yaitu: 1) Menolak digauli karena suami tidak menafkahi. Jumhur Fuqaha' dari kalangan Hanafiyah, Hanabilah, dan salah satu Pendapat paling valid dari Syafi'î menyatakan bahwa istri boleh menolak untuk digauli dan bahkan boleh keluar untuk bekerja tanpa izin. menurut Zhahiriyah dan salah satu pendapat Imam Syafi'î menyatakan bahwa istri tidak memiliki hak untuk menolak digauli. 2) Menolak digauli karena suami tidak mau membayar mahar mu'ajjal (kontan). Menurut jumhur ulama Hanafiyah, Malikiyah, Syafi'iyah, dan Hanabilah istri punya hak untuk digauli dan bepergian. Zhahiriyah berpendapat sebaliknya bahwa seorang istri tidak boleh menolak digauli karena suami tidak membayar mahar mu'ajjal. 3) Menolak digauli karena sakit. Jumhur ulama dari kalangan Hanafiyah, Malikiyah, Syafi'iyah, Hanabilah, dan Zhahiriyah sepakat bahwa istri punya hak untuk menolak digauli jika sakit. 4) Istri menolak digauli karena suami sakit yang bisa menular kepadanya. 5) Istri menolak digauli karena dia sedang melaksanakan ibadah wajib yang terbatas waktunya (wajib mudhayyaq). 6) Menolak digauli karena hendak dilakukan di depan pembantu atau istri suaminya yang lain, 7) Menolak digauli karena ada maksiat pada jima' tersebut, seperti di dubur, atau dalam keadaan sedang haid. ${ }^{44}$

Menolak ajakan suami untuk berjimak tanpa alasan yang syar'i adalah salah satu bentuk kekerasan seksual terhadap suami, karena pada saat itu, istri telah mengabaikan hak suami dalam persoalan seksual.Istri yang menolak untuk digauli dikategorikan sebagai nusyuz khafi, terkait dengan sanksi hukumnya, para ulama berbeda pendapat: 1) Jumhur ulama dari kalangan Hanafiyah, Zhahiriyah dan sebagian Malikiyah menyatakan bahwa jika istri menolak digauli tetapi tidak keluar dari rumah maka dia

\footnotetext{
${ }^{43}$ al-Bukhari, Shahih Al-Bukhari, 1324.

${ }^{44}$ Qarut, Mauqifu Al-Islam Min Nusyuz, Al-Zaujayn Aw Ahadihima Wama Yatba'u Dzalika Min Ahkamin (Dirasah Muqaranah), 117-24.
} 
tetap memiliki hak nafkah, 2) Syafi'iyah, jika istri menolak digauli tapi suami tetap menggaulinya, maka istri tetap dapat hak nafkah. Jika penolakan istrinya membuat suaminya tidak menggaulinya, maka hak nafkahnya gugur, 3) Hanabilah dan pendapat yang masyhur di kalangan Malikiyah. Istri tidak dapat nafkah kalau menolak digauli meskipun tidak keluar rumah. Jadi ulama berbeda pendapat tentang gugurnya hak nafkah istri jika istri menolak untuk digauli. Tapi yang pasti, sebagaimana hadits diatas, istri yang menolak untuk digauli berdosa.

Kedua, men-zhihar suami. Zhihar pada masa jahiliyah dan dalam syariat Islam pada dasarnya adalah ucapan suami kepada istri yang mempersamakan punggung istrinya dengan punggung ibunya dengan niat untuk mengharamkan istrinya kepadanya. Tetapi jika ada seorang istri yang mempersamakan punggung suaminya dengan punggung ayahnya dengan niat untuk mengharamkan suaminya tersebut, para ulama berbeda pendapat: ${ }^{45}$ 1) Menurut Malik dan Syafi'i tidak berlaku hukum zhihar terhadap istri, 2) Perempuan tersebut wajib membayar kafarat sumpah. ${ }^{46}$ 3) Perempuan tersebut wajib membayar kafarat zhihar. Ketika istri mempersamakan punggung suami dengan punggung ayahnya dengan maksud untuk mengharamkannya atau istri tersebut tidak mau digauli suaminya, maka tindakan ini adalah tindakan yang bertentangan dengan asas dan kewajibannya terhadap suami untuk mempergaulinya dengan baik (mu'asyarah bil ma'ruf). Sehingga apa yang dilakukan oleh istri ini bisa dikategorikan sebagai kekerasan seksual terhadap suaminya, karena tindakan ini adalah upaya istri agar suami tidak mendapatkan hak seksualnya.

Kekerasan Psikis, termasuk dalam kategori kekerasan psikis yang dilakukan istri kepada suami antaralain: Pertama, keluar rumah tanpa izin suami. Ulama Hanabilah menyatakan dengan tegas tentang keharaman seorang istri untuk keluar rumah tanpa izin dari suami:

$$
\text { ويحرم على الزوجة الخروج بلا إذن زوجها، لأن حق الزوج واجب فلا يجوز تركه بما ليس بواجب. } 47 \text { النوان }
$$

Artinya: "Haram bagi istri untuk keluar rumah tanpa izin suaminya, karena hak suami adalah kewajiban bagi istrinya, maka tidak boleh ditinggalkan kecuali untuk sesuatu yang wajib pula."

Jumhur ulama dari kalangan Hanafiyah, Syafiiyah, Hanabilah dan salah satu pendapat yang masyhur dari Malikiyah menyatakan bahwa jika seorang istri keluar rumah tanpa izin dari suami, maka hak nafkah istri gugur hingga ia balik ke rumahnya. ${ }^{48}$ Kedua, puasa sunnah tanpa izin suami. Berpuasa sunnah pada dasarnya dianjurkan untuk semua muslim, laki-laki maupun perempuan. Hanya saja, khususnya perempuan dalam posisinya sebagai istri, ada aturan tambahan yang disampaikan oleh Rasulullah saw, yaitu hendaknya istri yang mau berpuasa meminta izin kepada suaminya, sebagaimana sabdanya:

\footnotetext{
${ }^{45}$ Ibnu Rusyd, Bidayatul Mujtahid, 522.; Muhammad 'Ali al-Shabuni, Rawai' al-Bayan Tafsir Ayat alAhkam, Juz II, 531.

${ }^{46}$ Kaffarat sumpah adalah memilih diantara ketiga hal berikut: (1) membebaskan budak yang mukmin, (2) memberi makan sepuluh orang miskin masing-masing satu mud atau memberi pakaian masing-masing, (3) jika tidak mampu puasa tiga hari. Mushthafa Dib al-Bugha, Al-Tadzhib, (Surabaya: Toko Kitab alHidayah, tt), 252-253, Lihat: Qs. Al-Maidah: 89.

${ }^{47}$ Manshur bin Yunus bin Idris al-Buhuti, Kasysyafu al-Qina', Juz III, 117. Sebagaimana dikutip oleh Abdul Karim Zaidan, Al-Mufashshal fi Ahkam al-Mar'ah, Juz VII, 290.

${ }^{48}$ Qarut, Mauqifu Al-Islam Min Nusyuz Al-Zaujayn Aw Ahadihima Wama Yatba'u Dzalika Min Ahkamin (Dirasah Muqaranah), 124.
} 


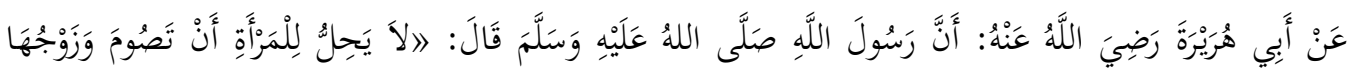

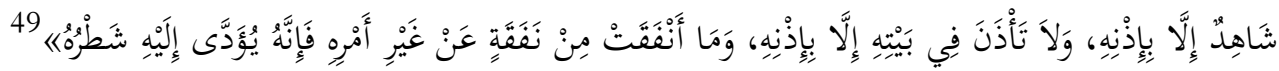

Artinya: "Dari Abu Hurairah ra: bahwasanya Rasulullah saw bersabda: tidak halal bagi seorang istri yang suaminya ada untuk berpuasa tanpa seizin suaminya, tidak mengizinkan orang lain masuk ke rumahnya tanpa seizin suaminya, dan jika istri memberikan sedekah dari harta suaminya tanpa sepengetahuannya, maka suaminya mendapatkan separuh pahala" (HR. Bukhari)

Ibnu Hajar dalam fath al-bari ketika membahas hadits tersebut menjelaskan bahwa jumhur ulama sepakat tentang keharaman berpuasa bagi seorang istri yang tidak meminta izin kepada suaminya. Al-Nawawi dalam syarh al-muhadzdzab menyatakan bahwa sebagian ulama menghukuminya makruh. Seorang istri yang berpuasa tanpa izin, puasanya tetap sah tapi diiringi dengan dosa. Dalam syarh muslim al-Nawawi menjelaskan bahwa sebab pengharaman ini adalah karena suami punya hak untuk menggauli (istimta') istrinya kapan saja, dan hak suami tersebut wajib ditunaikan langsung dan tidak boleh hilang hanya karena ibadah yang sunnah. ${ }^{50}$

Ketiga, tidak berterima kasih kepada suami. Dalam kehidupan rumah tangga, Islam menentukan bahwa yang bertugas dan berkewajiban mencari nafkah adalah suami. Ketika suami sudah menunaikan kewajibannya mencari nafkah tapi istri tidak memberikan penghormatan yang selayaknya bagi suami, maka sikap demikian tentu saja akan menyakiti perasaan suami. Oleh karena itu, Rasulullah memberikan peringatan kepada istri agar menghormati dan berterima kasih kepada suaminya:

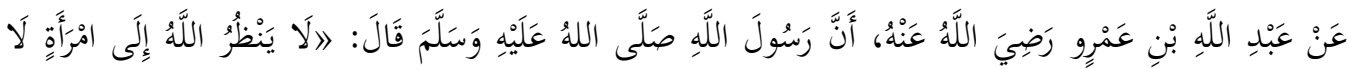

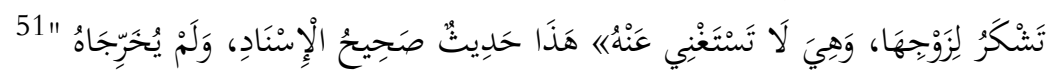

Artinya: "Allah tidak melihat kepada wanita yang tidak berterima kasih kepada suaminya, padahal dia bergantung kepadanya." (HR. Hakim)

Keempat, Berzina dengan laki-laki lain. Perzinaan adalah salah satu dosa besar yang dilarang di dalam Islam, di dalam al-Quran setidaknya Allah tiga kali melarangnya yaitu dari surah al-Isra' (17) ayat 32, al-Nur (24) ayat 2 , dan al-Furqan (25) ayat 68. Perzinaan seorang istri adalah salah satu bentuk kekerasan psikis terhadap suaminya, karena hal itu selain memang dilarang dalam agama, juga akan menyakiti perasaan suaminya. Sanksi hukum bagi istri yang berzina adalah rajam jika bisa dihadirkan empat orang saksi atau ada pengakuan dari istri. Jika suami tidak bisa menghadirkan empat orang saksi dan istri tidak mengakui, maka bisa dilakukan sumpah li'ân diantara keduanya. Konsekuensi hukum dari dilaksanakannya $l i$ 'ân antara suami dan istri adalah: 1) Gugurnya had bagi suami dan istri, 2) Putusnya perkawinan, 3) Keduanya haram menikah kembali untuk selama-lamanya, 4) Terputusnya hubungan nasab anak yang dili'ân dengan ayah yuridisnya.

Jika perzinaan terjadi sebelum suami menggaulinya, dalam sebuah riwayat dinyatakan:

\footnotetext{
${ }^{49}$ al-Bukhari, Shahih Al-Bukhari, 1325.

${ }^{50}$ Hajar, Fathul Bari, 296.

${ }^{51}$ al-Hakim al-Naisaburi, Al-Mustadrak 'Ala Al-Shahihayn, 2nd ed., Juz 2 (Beirut: Dar al-Kutub alIlmiyah, 2002), 207.
} 


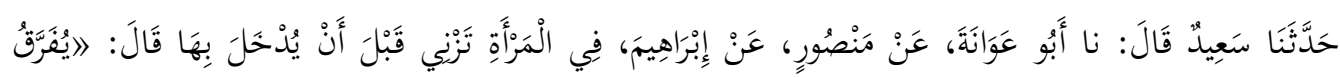

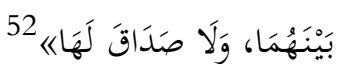

Artinya: "Sa'id menceritakan kepada kami, dia berkata terlah menceritakan kepada kami Abu Awanah dari Manshur dari Ibrahim tentang seorang istri yang berzina sebelum digauli oleh suaminya. Ibrahim menyatakan: keduanya diceraikan dan istri tersebut tidak memperoleh mahar"

Kekerasan Finansial, termasuk dalam bentuk kekerasan finansial yang dilakukan istri terhadap suami yaitu ketika istri membelanjakan harta suami tanpa izin. Seorang istri tidak boleh membelanjakan harta suaminya, atau mensedekahkan atau memberikan sebagian harta suaminya tanpa seizin suami. Ada beberapa riwayat hadits yang melarang perbuatan tersebut yang diantaranya diriwayatkan oleh Imam Tirmidzi berikut:

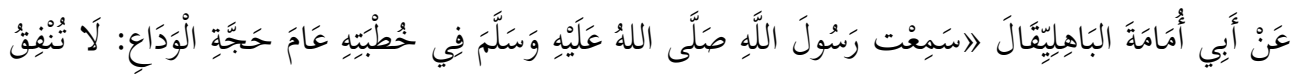

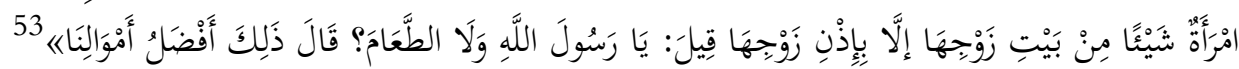

Artinya: "Dari Abu Umamah al-Bahili berkata: saya mendengar Rasulullah dalam khutbahnya pada haji wada': seorang istri tidak boleh menafkahkan sesuatu dari rumah suaminya tanpa seizin dari suami. Kemudian ada yang bertanya: wahai Rasulullah bagaimana kalau makanan? Rasulullah menjawab: itu adalah harta kita yang paling berharga".

Dalam riwayat Abu Daud juga disebutkan bahwa Rasulullah saw bersabda:

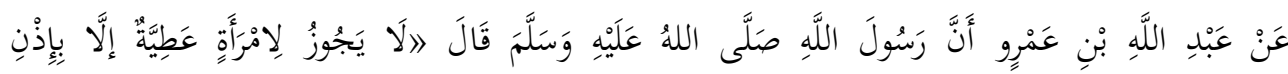

$$
\begin{aligned}
& \text { زَوْْجهَا } 54
\end{aligned}
$$

Artinya: "Dari Abdullah bin Amr bahwasanya Rasulullah saw bersabda: Seorang istri tidak boleh memberikan sesuatu tanpa seizin suaminya".

Dalam riwayat Abu Daud dinyatakan bahwasanya Abu Hurairah ditanya tentang seorang istri yang mensedekahkan harta suaminya? Abu Hurairah menjawab: tidak boleh, kecuali makanan pokok, pahalanya untuk keduanya, dan istri tersebut tidak boleh menggunakan harta suaminya tanpa seizin dari suaminya. Ibnu Razin al-'Abdari dalam kitab Jami'-nya menambahkan bahwa jika suaminya memberikan izin kepada istri untuk mensedekahkannya, maka pahalanya dibagi untuk suami istri tersebut, tapi jika istrinya mensedahkan tanpa izin dari suaminya, maka pahalanya untuk suaminya, dan dosanya untuk istrinya. ${ }^{55}$ Berdasarkan hadits-hadits tersebut bisa disimpulkan bahwa istri yang membelanjakan harta suaminya tanpa seizin suami, maka dia berdosa.

\section{Kesimpulan}

\footnotetext{
${ }^{52}$ Said bin Manshur bin Syu'bah al-Khurasani al-Makki, Sunan Said Bin Manshur, Juz 1 (Beirut: Dar alKutub al-Ilmiyah, n.d.), 220.

${ }^{53} \mathrm{Abu}$ Isa Muhammad bin Isa bin Saurah, Sunan Al-Tirmidzi, 2nd ed. (Riyadh: Maktabah al-Maarif li alNasyr wa al-Tauzi, 1417), 168.

${ }^{54}$ Abu Daud Sulaiman bin al-Asy'ats al-Sijistani, Sunan Abi Daud (Beirut: Dar al-Fikr, 2005), 667.

${ }^{55}$ Muhammad bin Ahmad bin Salim al-Safarayni al-Hambali, Ghidzaul Albab Syarah Manzhumah AlAdab (Beirut: Dar al-Kutub al-Ilmiyah, 1996), 310.
} 
Berdasarkan uraian yang telah disajikan, ada dua kesimpulan yang bisa disampaikan, yaitu: 1) Perbuatan yang menyebabkan terkuranginya atau hilangnya hak dari masing-masing suami atau istri adalah termasuk kekerasan dalam rumah tangga (KDRT) baik kekerasan seksual, fisik, psikis, maupun finansial, 2) Terhadap KDRT yang dilakukan oleh masing-masing suami atau istri hukum Islam memberikan sanksi ('uqubah) berupa hukuman di akhirat (dosa), kaffarat atau ta'zir.

\section{Daftar Pustaka}

Al-Baghawi, Abu Muhammad Al- Husain bin Mas'ud. Tafsir Al-Baghawi: Ma'alim AlTanzil. Jilid 8. Riyadh: Dar Thaybah, 1412.

Al-Syafi'i, Muhammad bin Idris. Al-Umm. 1st ed. Juz 6. Dar al-Wafa' Li al-Thiba'ah wa al-Nasyr wa al-Tauzi', 2001.

ani, Muhammad bin Isma'il al-Shan'. Subulu Al-Salam Syarh Bulugh Al-Maram. Juz 3. Riyadh: Maktabah al-Ma'arif li al-Nasyr wa al-Tauzi', 2006.

Bukhari, Abu Abdillah Muhammad bin Ismail al-. Shahih Al-Bukhari. Beirut: Dar Ibnu Katsir, 2002.

Hajar, Ahmad bin 'Ali Ibnu. Fathul Bari. Juz 9. Riyadh: Maktabah al-Salafiyah, 1379.

Hambali, Muhammad bin Ahmad bin Salim al-Safarayni al-. Ghidzaul Albab Syarah Manzhumah Al-Adab. Beirut: Dar al-Kutub al-Ilmiyah, 1996.

Kodir, Faqiuddin Abdul Kodir. "Kekerasan Dalam Rumah Tangga (KDRT) Perspektif Islam: Kompilasi Awal Teks-Teks Hdis Rujukan." Mahkamah: Jurnal Kajian Hukum Islam 1, no. 1 (2016).

Makki, Said bin Manshur bin Syu'bah al-Khurasani al-. Sunan Said Bin Manshur. Juz 1. Beirut: Dar al-Kutub al-Ilmiyah, n.d.

Mughniyah, Muhammad Jawad. Fiqih Lima Mazhab. Translated by Masykur A.B., Afif Muhammad, Idrus Al-Kaff. 28th ed. Jakarta: Penerbit Lentera, 2013.

Naisaburi, al-Hakim al-. Al-Mustadrak 'Ala Al-Shahihayn. 2nd ed. Juz 2. Beirut: Dar alKutub al-Ilmiyah, 2002.

Qarut, Nur Hasan. Mauqifu Al-Islam Min Nusyuz Al-Zaujayn Aw Ahadihima Wama Yatba'u Dzalika Min Ahkamin (Dirasah Muqaranah). Mekkah: Jami'atu Ummul Qura, 1995.

Rusyd, Ibnu. Bidayatul Mujtahid Wa Nihayah Al-Muqtashid. Beirut: Dar al-Kutub alIlmiyah, 2010.

Saurah, Abu Isa Muhammad bin Isa bin. Sunan Al-Tirmidzi. 2nd ed. Riyadh: Maktabah al-Maarif li al-Nasyr wa al-Tauzi, 1417.

Shabuni, Muhammad Ali al-. Rawai'u Al-Bayan Tafsiru Ayati Al-Ahkam Min AlQur'an. 3rd ed. Juz 2. Beirut: Muassasah Manahilu al-'Irfan, 1981.

Sijistani, Abu Daud Sulaiman bin al-Asy'ats al-. Sunan Abi Daud. Riyadh: Maktabah al-Ma'arif li al-Nasyr wa al-Tauzi', 1417. Sunan Abi Daud. Beirut: Dar al-Fikr, 2005.

Soekanto, Soerjono. Pengantar Penelitian Hukum. Jakarta: UIN Press, 1986.

Sukardi, Didi. "Kajian Kekerasan Rumah Tangga Perspektif Hukum Islam Dan Hukum Positif." Jurnal Mahkamah 9, no. 1 (2015).

Syaibah, Abu Bakr Abdullah bin Muhammad bin Abi. Musnad Ibnu Abi Syaibah. Jilid 1. Riyadh: Dar al-Wathan, 1997.

Taimiyah, Ahmad Ibnu. Majmu' Al-Fatawa. Juz 32. Madinah: Mujamma' al-Malik Fahd Li Thiba'ah al-Mushhaf al-Syarif, 2004. 
Zaidan, Abdul Karim. Al-Mufashshal Fi Ahkam Al-Mar'ah Wa Al-Bayt Al-Muslim Fi Al-Syari'ah Al-Islamiyah. Juz 5. Beirut: Muassasah al-Risalah, 1993.

Al-Mufashshal Fi Ahkam Al-Mar'ah Wa Al-Bayt Al-Muslim Fi Al-Syari'ah AlIslamiyah. Juz 7. Beirut: Muassasah al-Risalah, 1993.

Zuhaili, Wahbah al-. Al-Fiqh Al-Islami Wa Adillatuhu. 2nd ed. Juz 7. Damaskus: Dar alFikr, 1985.

Al-Fiqh Al-Islami Wa Adillatuhu. 2nd ed. 9. Damaskus: Dar al-Fikr, 1985. 